\section{Gaps and barriers along the North Carolina agri-food value chain}

North Carolina agri-food value chain

Carol S. Kline 301

Department of Management, Appalachian State University, Boone, North Carolina, USA Leah Elizabeth Joyner

Carolina Farm Stewardship Association Raleigh, Pittsboro, North Carolina, USA

Jon F. Kirchoff

Department of Marketing and SCM,

East Carolina University, Greenville, North Carolina, USA

Alleah Crawford

Department of Hospitality Leadership,

East Carolina University, Greenville, North Carolina, USA

Stephanie Jilcott Pitts

Department of Public Health,

Brody School of Medicine, Greenville, North Carolina, USA

Elizabeth Wall-Bassett

Department of Nutrition Science,

East Carolina University, Greenville, North Carolina, USA

Christine Gurganus

Fleet Readiness Center East, Cherry Point, North Carolina, USA, and

Rebecca Dunning

Department of Horticulture,

North Carolina State University, Raleigh, North Carolina, USA

Received 24 June 2015 Revised 22 October 2015 Accepted 23 October 2015

\begin{abstract}
Purpose - The purpose of this paper is twofold: first, to formulate an exhaustive list of the issues, gaps, and barriers at each level of the agri-food value chain in North Carolina (NC), and second, to identify the issues of greatest importance to its members.

Design/methodology/approach - This research employed the Delphi technique in two stages of input. The first round of input was designed to create a comprehensive list of issues for each of nine "stages" of the agri-food value chain. In round two, the issues were prioritized.

Findings - The top ten responses of each stage were aggregated into themes that represent the most critical issues identified by respondents: connectedness within the value chain, access to markets and marketing, affordability/availability of food and food distribution, farm profitability, societal awareness, and education about healthy, local food, and supporting institutions.

The authors wish to express gratitude to East Carolina University for their support of this study: the Engagement and Outreach Scholars Academy, the Division of Research and Graduate Studies, and the Center for Sustainable Tourism. The work in this manuscript is based on a project conducted through the Engagement and Outreach Scholars Academy.
\end{abstract}


$\mathrm{BFJ}$

118,2

302

Originality/value - The findings could be used by practitioners to inspire innovation in food-related products, programs, processes, organization, and marketing. The findings can help farmers, institutions, food distributors, policy makers, and other members of the agri-food value chain to make decisions about food distribution and access in $\mathrm{NC}$ and in other states facing similar issues and circumstances. The findings of this research also have further reaching implications, such as the connectivity of members along the agri-food value chain, the impact of a strong agri-food value chain on agritourism and the potential value of state marketing initiatives.

Keywords Value chain, Delphi technique, Farm-to-market, Food systems, Value-added processing

Paper type Research paper

\section{Introduction}

Regional and local agriculture has been shown to support rural development, create jobs, and secure food production, positively impacting the health of residents and economies (Herath and Hill, 2013). However, even in regions with significant agricultural output and resources, residents and economies have not always benefited. Reasons for this disconnect between resources and expected benefits vary and are often context dependent (Bloom and Hinrichs, 2011). The underlying causes can be better understood by researching the issues that exist with the actors and within the activities that connect farms and other food producers to the end consumer, known as the agri-food value chain (Rominger et al., 2012; Passuello et al., 2015). Identifying issues along the agri-food value chain could help its members (e.g. farmers, food producers, food retailers, and consumers) mitigate these issues, and help improve the chain's effectiveness and impact on local and regional economies (Bloom and Hinrichs, 2011; Kaplinsky and Morris, 2013; Grandori, 2015).

Identifying issues that exist among farmers, food producers, distributors, consumers, and institutional members of the agri-food value chain requires a comprehensive understanding of the challenges presented to these different entities (Curtis et al., 2010; Taylor, 2005). This understanding can be accomplished by examining the context in which the stakeholders operate and make decisions, and by drawing out the problems, rifts, and barriers, from the stakeholders' perspective, that exist in food distribution, food access, and food demand (Herath and Hill, 2013; Passuello et al., 2015). For example, waste and inefficiencies can increase supply uncertainty from the perspective of food retailers, while problems with distribution create demand uncertainty for farmers (Kaipia et al., 2013).

This research seeks to explore agri-food value chain issues in the US state of North Carolina (NC). NC is agriculturally rich and severs as an attractive culinary tourist destination. At the same time and somewhat paradoxically, $\mathrm{NC}$ has a large rural population that is economically distressed (Curtis et al., 2010). Nearly 30 percent of the population lives in 85 rural counties (Herath and Hill, 2013). Furthermore, over 60 percent of rural residents work in agriculture, but have a higher rate of poverty than their urban counterparts (Curtis et al., 2010; Herath and Hill, 2013). Thus, NC is used as the context of this research because of the dichotomist relationship between its agricultural prowess and rural economies. The purpose of this study is twofold and reflected in the following research questions:

$R Q 1$. What are the gaps, barriers, and disconnects perceived by members of the NC agri-food value chain?

$R Q 2$. How are these gaps, barriers, and disconnects similar and different among the different members of the NC agri-food value chain? 
Both questions are addressed by using a Delphi technique methodology with members of the NC agri-food value chain as the participants, from the perspective of a value chain analysis. The findings can help members of the agri-food value chain make decisions about the agricultural industry, food distribution, and economic development in $\mathrm{NC}$ and in other states facing similar circumstances. The findings of this research also have further reaching implications, such as how the connectivity among members improves the efficiency and effectiveness of the chain and the potential value of state marketing initiatives to members of the agri-food value chain.

North Carolina agri-food value chain

303

\section{Background}

Food value chains

A value chain is set of organizations involved in different processes and activities that produce value in the form of products and services and distribute them to the end consumer (Christopher, 2010). The initial focus of value chain research was on individual businesses and performance, but now the concept encompasses a wider set of issues including social benefits, regional and local economic development, and consumer satisfaction (Kaplinsky and Morris, 2013). Value chains exist because each member of the chain adds value to products and services through activities to which they are best suited, and allows other members to do the same (Porter, 1985). For example, farmers grow crops and sell them to restaurants that in turn create dishes that are sold to consumers. In this way, the farmers maximize value by using best growing techniques, and the restaurant maximizes value through expertise in food preparation. The end consumer realizes the value through their purchases (Christopher, 2010). Collaboration, shared goals, and understanding multiple perspectives of the upstream and downstream value chain partners increase the chances of success for the different members (Mentzer et al., 2001).

Food value chains are unique and differentiated from other product value chains largely due to the perishable nature of inventory, which significantly affects the logistics of each stage involved in the value chain system ( $\mathrm{Yu}$ and Nagurney, 2013). The literature is replete with research on food safety, quality, and waste in value chains from the perspective that the interactions among the value chain members and their activities tell a more complete story (Kirezieva et al., 2013; Tran et al., 2013). Analyzing issues from the value chain perspective has also been used to uncover opportunities for improved efficiency in food value chains through the understanding sources of variability such as consumer demand, inventory, and seasonality (Georgiadis et al., 2005).

\section{Value-chain analysis}

Value chain analysis allows researchers to deal with the dynamic linkages that are part of the inter-member nature of value chains, rather than static and bounded research on individual members (Kaplinsky and Morris, 2013). Problem solvers must move away from attempts to resolve singular issues and toward studying and reacting to systems as a whole (Meadows andWright, 2008; Kaplinsky and Morris, 2013). Investigating attitudes and circumstances from the viewpoint of all members of agri-food value chains is key to understanding the relationships and dynamics among the members (Leat and Revoredo-Giha, 2006).

Value chain analysis also allows researchers to uncover the waste among the different entities and processes of a value chain and may ultimately help reduce 
$\mathrm{BFJ}$

118,2

304

inefficiencies and increase productivity (Hines et al., 1998). Furthermore, value chain analysis can has uncovered how open communication and sharing of important information among members of the agricultural industry can reduce the likelihood of food contamination, improve visibility within food systems, and decrease waste (Kaipia et al., 2013). This study incorporates a value chain analysis of the NC agri-food value chain to ascertain key food system issues and to help researchers, practitioners, and local food system resolve problems.

\section{Setting}

Agriculture and agribusiness play a primary role in the NC economy. The combined food-related industries in NC (agriculture, fishing, food processing, and outlets) employ over 420,000 workers and contribute $\$ 78$ billion to the economy (Herath and Hill, 2013; North Carolina Department of Commerce, 2014). NC enjoys significant and diverse agriculture and aquaculture output (Curtis et al., 2010), with food producers in coastal, plains, foothills, and mountain regions growing and harvesting livestock, as well as a wide variety of crops and seafood. The southeastern region of the state grows sweet potatoes, peanuts, soybeans, grapes, blueberries, and a wide range of animal proteins. Western NC is conducive to the cultivation of fruit orchards as well as vegetable production (Curtis et al., 2010).

The diversity and abundance of food products in NC, coupled with community activism toward health issues and increased popularity of farmers markets, has driven demand for local foods. As a result, a number of $\mathrm{NC}$ farmers throughout the state representing all areas of the state's food production industry are turning to smaller markets that allow direct to consumer sales of food. These initiatives are supported by federal public health funding such as the Community Transformation Grant Project from the US Centers for Disease Control and Prevention. The interest in and marketing of local foods has also helped promote $\mathrm{NC}$ as a tourist destination. $\mathrm{NC}$ is ranked the sixth most visited state in the USA, and its tourism industry contributes $\$ 19.4$ billion in revenue to the state's economy on an annual basis (North Carolina Department of Commerce, 2013).

Culinary tourism has the potential to strengthen a sense of regional identity, involving supply chain links between farms, restaurants, and consumers (Everett and Aitchison, 2008). Inwood et al. (2009) report that many chefs find that the taste of the dishes they serve was enhanced when those dishes included high quality and in season local foods. However, the researchers also noted the absence of strong connections between restaurants and farm groups (Inwood et al., 2009). Indeed, despite the wealth of research on culinary tourism motivations, there remains a gap in the literature concerning the supply chain linkages between producers and distributors (such as farmers markets, festival operators, and restaurants) that compose the food trails that allow tourists to access local foods (Smith and Honggen, 2008).

Despite the rise in popularity of food-related tourism, not everyone can afford the luxury of culinary travel. The urban and rural poor within $\mathrm{NC}$ rely heavily on organizations who work in food access. The term food desert is an area in which consumers do not have access to healthy and affordably priced foods due to either physical or economic barriers (Weatherspoon et al., 2012). Food deserts exist across geographic regions of $\mathrm{NC}$ and have been linked to negative impacts on human health manifesting in obesity, diabetes, and heart disease (Laria et al., 2009). In fact, while the national average of food insecure households was at 14.5 percent in 2012, NC's average of 17.1 percent has drastically increased from the 13.2 percent average in 2005 (United States Department of Agriculture, 2013). 


\section{Methodology}

\section{Delphi technique}

This research employed the Delphi technique to compose a list of agri-food value chain issues. The Delphi technique is recognized as a valuable tool for collecting expert opinions (Green et al., 1990; Padel and Midmore, 2005) and a qualitative "judgmental" research technique that provides researchers with access to previously unexplored issues (Garrod and Fyall, 2005). Reliability is reinforced by eliciting the opinions of multiple experts, allowing each expert to review the opinions of other participants, and the assurance of anonymity which avoids issues of bias or coercion that may be presented during focus group or discussion scenarios (Ogden et al., 2005). Each member of the group provides individual recommendations or opinions on the central issues. These ideas are then circulated to the other participating members of the group so that a consensus may be formed through collaborative review. Because of its quantitative, expert-based nature, the Delphi technique is useful in situations where statistical options are not practical. The technique also allows respondents time to reflect and provides them an equal opportunity to contribute.

\section{Round 1 (R1) - formulating list of issues}

The first step in the methodology was to formulate a preliminary list of issues along the value chain. Sources for this preliminary list were varied and are detailed in the reference section: technical and research reports, academic research articles, conference and meeting presentations, and professional experiences of the research team (see Kline et al., 2013 for a detailed list). After the first draft of issues was created, each issue was assigned to a "stage" within the agri-food value chain. Ultimately, nine stages were selected: growth and production, farmer access to market, value-added processing, marketing, dining outlet, institution, retailer, direct to market outlet, and food access assistance (Table I). The issues were then assigned to the most appropriate stage(s), generating an initial aggregated list. Additionally, a group of experts reviewed and added to the list to improve the face validity of the named stages.

The Delphi expert panel was created by using three sources: recommendations from project partners; existing organizational lists, such as the membership list from the $\mathrm{NC}$ Agromedicine Institute, the members of the NC Local Foods Policy Council, and the tourism contacts for all NC counties; and recruitment solicitation through statewide and regional listservs. The statewide and regional listservs included an agritourism association (statewide), local foods (one statewide, two regional), niche meats (statewide), municipal and county planning (statewide), government agencies involved in "greening" programs (statewide), a network of people interested in entrepreneurship and small business (statewide), and a group interested in environmental education (statewide).

Once the experts had been identified, they were sent a survey containing the previously aggregated list of issues along the agri-food value chain. In R1 of the survey, the experts were asked to review the list of issues for the "stage" of the agri-food value chain with which they were most familiar. Then they were asked to identify any issues missing from the list for that particular segment of the agri-food value chain. The division of the issues into stages and sectors was done for two reasons. First, so as not to over-burden survey respondents, they were asked to select only one stage with which they most identified. This was done to reduce the volume of potential issues that the respondent would need to consider. The second reason was to identify the most critical issues within specific stages of the value chain. Responses from R1 participants were compiled and then added to the aggregate list of issues (see Table II for number of issues within each stage).
North Carolina agri-food value chain 
$\mathrm{BFJ}$

118,2

306

Farmer access to

markets

Value-added

processing

Marketing

Dining outlets

Institutions

Retailers

Table I.

Descriptions of the agri-food value chain stages outlets
Description

This stage is relevant to animal protein, commodity crops, and produce.

Processes that are involved at this stage include, but are not limited to: growing from seed, growing from stock, harvesting, treatment, storage, and packaging that happens on the farm

This stage deals with the linkages that connect the primary production stage with the downstream members of the supply chain including outlets for production and methods of distribution, as well as related issues that impact farmers, distributors, and the food system suppliers as they fill market demand This stage includes large-scale food manufacturing, and small-scale food processing. Food products become "value-added" when it is processed in a way that gives the raw product an incremental value above its original market worth, or the food is cultivated in a way that differentiates it from similar products in the market. Common value-adding processes are washing, cutting, canning/ jarring, freezing, drying, juicing, baking, brewing, fermenting, and others. Common value-adding differentiations include organic growing practices, sustainable operations, and geographic demarcation

This category includes both marketing and sales. Marketing includes branding, messaging, advertising, promotions, and other techniques are included in marketing. Sales refers to pricing, profit margins, profit sharing, subsidies, premiums, among others

This category includes lodging, restaurants, catering, food trucks, and food festivals. These members of the supply chain offer prepared foods to the end consumer

These outlets include K-12 schools, college campuses, convention centers, hospitals, and prisons, and connect to large groups of consumers, who typically depend on these outlets for daily sustenance. These supply chain members are unique and play key roles in national health

This category refers to the retailers of the food system, including supermarkets, grocers, corner stores, and buying clubs. Each of these types of retailers has different supply chain structures and face different sets of issues, despite the similar functions that they maintain in the overall food supply chain

Direct-to-market Produce stands, famers' markets and Community Supported Agriculture (CSA's) connect consumers directly with farmers for the purchasing of food products shortening the distance food must travel to reach consumers This stage refers to the mechanisms that support food security, food aid, and hunger relief activities in $\mathrm{NC}$ and includes multiple supply chain sequences (growing, procurement, storage, adding value, and distribution activities) for a specific audience, and emergency-response and disaster-relief programs

\section{Round 2 (R2) - prioritization of issues}

The research team reviewed responses from R1, combined similar responses, and then formulated the new list of issues into a second survey. Additionally, issues that exist in multiple stages were added to the relevant categories. R2 of the survey was distributed by asking participants to choose the top 20 most important issues in their selected stage of the value chain. The purpose of this was to identify which issues in each segment of the agri-food value chain the respondents felt were most important; and to distinguish which issues should be included in a survey to be distributed to the public in future research efforts. In the final stage, content analysis was employed to code the top responses from each stage into overall themes. Three coders underwent process training to ensure thematic agreement and to bolster inter-coder reliability (Hsieh and Shannon, 2005). 


\begin{tabular}{|c|c|c|c|}
\hline Stage & $\begin{array}{c}\text { Number of items in Round } 1 \text { original } \\
\text { list }\end{array}$ & Number of items added in Round & $\begin{array}{r}\text { North carolina } \\
\text { agri-food }\end{array}$ \\
\hline Growth and production & 173 & 107 & \\
\hline Farmer access to markets & 117 & 18 & \\
\hline Value-added processing & 93 & 11 & \\
\hline Marketing & 96 & 20 & 07 \\
\hline Dining outlets & 44 & 24 & 8 \\
\hline Institutional sector & 32 & 35 & \\
\hline Retail sector & 87 & 19 & Table II. \\
\hline Direct-to-markets outlets & 48 & 34 & Number of survey \\
\hline Food access assistance & & & items (original and \\
\hline sector & 37 & 24 & added issues) \\
\hline Total & 727 & 292 & Round 1 \\
\hline
\end{tabular}

\section{Results}

The sample in R1 ranged (according to response rate) from 206 to 212 and 195 to 199 in R2, yielding a 32.5-35.3 percent response rate. In R1 of the survey, 57.3 percent of respondents were female, with a similar distribution of 55.6 percent in R2. The majority of respondents were between 50 and 59 years old $(\mathrm{R} 1=28.5$ percent, $\mathrm{R} 2=32.8$ percent), closely followed by the 40-49 years old group $(\mathrm{R} 1=25.1$ percent, $\mathrm{R} 2=22.2$ percent). The majority of respondents reported a race/ethnicity of white, non-Hispanic ( $R 1=91.4$ percent, $\mathrm{R} 2=89.2$ percent). Demographic information of the panel participants can be found in Table III.

The majority of respondents worked in the public sector $(\mathrm{R} 1=39.6$ percent; $\mathrm{R} 2=41.2$ percent), while involvement in the private $(\mathrm{R} 1=22.2$ percent; $\mathrm{R} 2=20.6$ percent) and non-profit sectors $(\mathrm{R} 1=23.6$ percent; $\mathrm{R} 2=20.6$ percent) was fairly evenly split within each round. Most respondents worked on farm/food issues locally $(\mathrm{R} 1=42.2$ percent; $\mathrm{R} 2=43.4$ percent), while roughly one-fifth worked regionally $(\mathrm{R} 1=20.4$ percent; $\mathrm{R} 2=19.4$ percent), and statewide $(\mathrm{R} 1=19.9$ percent; $\mathrm{R} 2=22.4$ percent) (Table III). Overwhelmingly, participants worked in business/ management or were entrepreneurs themselves, followed by education and research, farming, and economic development/tourism. The majority of respondents in both rounds have been involved in their present occupation for more than a decade $(\mathrm{R} 1=52.1$ percent; $\mathrm{R} 2=58.0$ percent). Very few respondents had been in their present occupation for less than three years $(\mathrm{R} 1=9.7$ percent; $\mathrm{R} 2=10.8$ percent).

Respondents were asked to indicate all of the ways in which they are involved with food, personally and professionally, by checking a list of activities or offering their own (Table IV). The reported food involvement varied widely, with respondents citing involvement home gardening $(\mathrm{R} 1=56.9$ percent; $\mathrm{R} 2=52.5$ percent), education/training $(\mathrm{R} 1=43.6$ percent; $\mathrm{R} 2=46$ percent), economic development $(\mathrm{R} 1=38.9$ percent; $\mathrm{R} 2=31.3$ percent), and community development $(\mathrm{R} 1=40.3$ percent; $\mathrm{R} 2=38.4$ percent).

Members of the Delphi panel were then asked to self-select which stage they belong to in the agri-food value chain, out of the eight identified possibilities. While most of the respondents chose the growth and production stage in $\mathrm{R} 1$ ( $\mathrm{R} 1=31.9$ percent), the distribution of those who selected the remaining supply chain stages was fairly even, ranging from 6.3-12.1 percent. In R2, almost one third of respondents chose to respond to the growth and production stage $(\mathrm{R} 1=32.5$ percent). The respondent distribution of those who selected the remaining supply chain stages were fairly even, ranging from 7.2-11.9 percent, with the exception of the retailer sector (3.1 percent) (Table V). 
$\mathrm{BFJ}$

118,2

\begin{tabular}{lcc}
\hline Variable & Round 1 & Round 2 \\
\hline Gender $(n=211 ; 196)$ & & \\
Female & $57.3 \%$ & $55.6 \%$ \\
Male & $42.7 \%$ & $44.4 \%$
\end{tabular}

308

Age $(n=207 ; 198)$

19-29 years old

30-39 years old

40-49 years old

50-59 years old

$60+$ and older

$\begin{array}{rr}8.7 \% & 6.6 \% \\ 21.3 \% & 19.2 \% \\ 25.1 \% & 22.2 \% \\ 28.5 \% & 32.8 \% \\ 16.4 \% & 19.2 \%\end{array}$

Racelethnicity ( $n=209$; 195)

American Indian

$1.4 \% \quad 1.0 \%$

Asian

Black or African-American

Hispanic/Latino

Pacific Islander

White, non-Hispanic

Mixed race

$0.5 \% \quad 2.6 \%$

$3.3 \% \quad 2.6 \%$

$0.5 \% \quad 1.0 \%$

$0.0 \% \quad 0.0 \%$

$91.4 \% \quad 89.2 \%$

Employment sector $(n=212 ; 199)$

Public

$2.9 \% \quad 3.6 \%$

Private

Non-profit

Hybrid

Retired

Student

Unemployed

$39.6 \%$

$22.2 \%$

$41.2 \%$

$23.6 \%$

$20.6 \%$

$8.5 \%$

$20.6 \%$

$1.9 \%$

$10.6 \%$

$2.4 \%$

$3.5 \%$

$1.9 \%$

$1.5 \%$

Work involvement in farm/food ( $n=206$; 196)

Locally (one to three counties)

Regionally (more than three counties)

Statewide

$42.2 \%$

$20.4 \%$

$19.9 \%$

$17.5 \%$

$43.4 \%$

Beyond NC

$19.4 \%$

$22.4 \%$

$14.8 \%$

Table III.

Demographic and

Occupation ( $(n=210 ; 199)$

Business/management/marketing/ consulting/entrepreneurship $\quad 71 \quad 72$

Research/education

$51 \quad 50$

Farmer

27

Economic development/tourism

27

Health care

12

Planning

20

15

Environmental resources

Legal/attorney

Creative/arts/design

Disabled/retired

11

11

characteristics of

Delphi panel

participants

The top priorities identified by the Delphi panelists, according to the stage that they selected, are depicted in Table VI. The relationships among the various stages used in this study are depicted in Figure 1. The following sections discuss the important issues identified for each stage of the agri-food value chain. 


\begin{tabular}{|c|c|c|c|}
\hline$\underline{\text { Variable }}$ & Round $1(\%)$ & Round $2(\%)$ & North Carolina \\
\hline Roles in the food system $(n=211 ; 198)$ & & & value chain \\
\hline Advocacy & 28.9 & 24.2 & \\
\hline Agri-law & 4.3 & 2.5 & \\
\hline Agribusiness & 25.1 & 21.2 & \\
\hline Animal health/stewardship & 14.7 & 10.6 & 309 \\
\hline Aquaculture & - & 3.0 & 509 \\
\hline Board member & - & 23.7 & \\
\hline Business management & 19.0 & 19.2 & \\
\hline Community development & 40.3 & 38.4 & \\
\hline Community gardens & 25.1 & 27.3 & \\
\hline Consulting & 20.9 & 18.7 & \\
\hline Cooking/baking & 30.8 & 25.8 & \\
\hline Cooperatives/aggregator & - & 9.6 & \\
\hline Distributor & 17.1 & 13.6 & \\
\hline Economic development & 38.9 & 31.3 & \\
\hline Economics & 8.5 & 5.1 & \\
\hline Education/training & 43.6 & 46.0 & \\
\hline Farming/growing & 31.8 & 37.4 & \\
\hline Food access & 36.5 & 31.3 & \\
\hline Food service/hospitality & 13.3 & 12.6 & \\
\hline Food-faith issues & 8.5 & 8.1 & \\
\hline Funder/grantor & 3.3 & 6.6 & \\
\hline Grant writer & - & 22.7 & \\
\hline Grassroots efforts & 28.4 & 27.8 & \\
\hline Home gardening & 56.9 & 52.5 & \\
\hline Institutional farm-to-fork & - & 12.1 & \\
\hline Involved in food events/festivals & 37.4 & 29.8 & \\
\hline Labor/farmworker issues & 4.7 & 9.1 & \\
\hline Land/environmental stewardship & 37.9 & 27.8 & \\
\hline Marketing & 37.4 & 28.8 & \\
\hline Planning & - & 16.7 & \\
\hline Policy-making & 18.0 & 19.2 & \\
\hline Processing & 14.7 & 17.2 & \\
\hline Public health & 14.7 & 14.6 & \\
\hline Public health/nutrition & 20.4 & 16.2 & \\
\hline Research & 30.3 & 26.3 & \\
\hline Restaurant operations & 8.1 & 7.1 & \\
\hline Social equity & 21.3 & 21.7 & \\
\hline Tourism marketing & 15.2 & 9.6 & \\
\hline Trade association & 5.2 & 6.1 & Table IV. \\
\hline Volunteer & 25.6 & 24.7 & Food activity \\
\hline Waste management & 6.2 & 9.1 & involvement of \\
\hline Youth development & - & 16.2 & participants \\
\hline
\end{tabular}

\section{Aggregated categories of issues}

The key issues identified through the Delphi study offer a number of insights into some of the primary concerns shared by the members of the agri-food value chain in NC. Interestingly, the critical issues cited by respondents who self-identified with a particular stage did not necessarily correspond with that stage, something that belies an interconnectedness, however constructed, among the different value chain members. 
Value chain stage/sector $(n=207 ; 194)$

$\begin{array}{lll}\text { Growth and production (seed to farm gate) } & 31.9 & 32.5\end{array}$

Farmer access to markets

Table V.

Percentage of participants in each agri-food value chain stage hospitals, and prisons and buying clubs

Direct-to-market outlets: produce stands, farmers markets, and community supported agriculture
10.8

7.2

7.2

Three phases of coding were used by all authors of this research to analyze the data. Three researchers initially categorized the data (open coding); the same three researchers then created interconnecting categories (axial coding). Finally, the remainder of the researchers authenticated coding and theme descriptions. Where there was disagreement, discussion ensued to gain consensus and revisions were made in the themes. The top ten responses of each stage were aggregated with similar responses into themes, regardless of the stage from which they originated; a total of 90 responses were analyzed during this stage. The researchers developed the themes by first analyzing the data individually, looking at the top responses and creating thematic structures to converge like-responses. Once each of the researchers completed their individual work, all of the themes were compared. Discrepancies were discussed and resolved, and a uniform aggregate list of themes emerged from the data. Seven distinct, yet related themes across all stages represented by participants in the Delphi study were revealed: connectedness issues, access to markets and marketing, availability of food distribution, affordability of food, farm profitability, societal awareness and education, and supporting institutions. Each theme is discussed in more detail in the following sections.

\section{Connectedness issues}

The overarching concern and interest of the participants seemed to be related to the issues of connectivity and access to other stakeholders in the value chain. Respondents from all of the stages noted connectedness issues, including access to processing facilities that work with small-scale producers, availability of distribution networks, building networks between producers, and dining outlets, policy that affects the relationship between institutions and local food systems, partnerships between local growers and distributors, and the creation of food hubs. Increased connectedness, sharing of important information and technology, and cooperation among the different members of the value chain can improve the efficiency and effectiveness of the value chain. Efficiencies are gained through streamlined distribution and reduced waiting times. Effectiveness is improved when cost savings from improved efficiency is passed on to the customers and consumers and through greater access to food products.

Connectedness was explicit in some cases, as in the case of retailers who have a stronger connection and relationship to farmers in the upstream value chain, and customers in the downstream value chain. Other participants had a more central focus on their organizations, 


\begin{tabular}{|c|c|c|}
\hline Stage & Description & \\
\hline $\begin{array}{l}\text { Growth and production (seed to farm } \\
\text { gate) }\end{array}$ & $\begin{array}{l}\text { State agency support } \\
\text { Long-term profitability potential } \\
\text { Access to capital, labor, land } \\
\text { Young farmer training } \\
\text { Succession planning } \\
\text { Good agricultural practices certification }\end{array}$ & value chain \\
\hline Farmer access to markets & $\begin{array}{l}\text { Buy local/organic movement } \\
\text { Markets providing fair compensation } \\
\text { State/local agency support } \\
\text { Cooperatives and aggregators } \\
\text { New distribution networks } \\
\text { Identifying regional demand } \\
\text { Agritourism } \\
\text { Creation of food hubs }\end{array}$ & \\
\hline Dining outlets & $\begin{array}{l}\text { Dining outlets networks } \\
\text { Availability and affordability of local/organic produce/ meat/ } \\
\text { seafood } \\
\text { Quality control through supply chain }\end{array}$ & \\
\hline Institutions & $\begin{array}{l}\text { Public and institutional policies that support buying local } \\
\text { Producer/distributor partnerships } \\
\text { Farming/cooking programs for youth }\end{array}$ & \\
\hline Retailers & $\begin{array}{l}\text { Availability, affordability, and variety of local/organic food } \\
\text { Mid-level distributors for mid-sized retailers } \\
\text { Distribution time and cost to distribute local foods } \\
\text { Transportation providers } \\
\text { Ownership of food system }\end{array}$ & \\
\hline Direct-to-market outlets & $\begin{array}{l}\text { Convenient access to affordable local produce } \\
\text { Promotion of farmers markets and community supported } \\
\text { agriculture } \\
\text { A sense of community } \\
\text { Creation of food hubs } \\
\text { Farmer profitability } \\
\text { Regulatory barriers }\end{array}$ & \\
\hline Food access assistance & $\begin{array}{l}\text { Need for increased demand in low-income communities } \\
\text { Availability/affordability of local/organic foods } \\
\text { Supplemental Nutrition Assistance Program-Electronic } \\
\text { Benefit Transfer infrastructure Support } \\
\text { for food microsystems } \\
\text { Creation of food hubs } \\
\text { Distribution of excess produce to low-income persons }\end{array}$ & $\begin{array}{r}\text { Table VI. } \\
\text { Top issues in each } \\
\text { stage of the value } \\
\text { chain as rated } \\
\text { among Delphi panel } \\
\text { participants }\end{array}$ \\
\hline
\end{tabular}

as in the case of food access assistance groups. Yet even these participants expressed concerns of the need for connectedness with other institutions and stages in the chain.

\section{Availability of food distribution}

Respondents also conveyed a concern for logistical issues related to the distribution channels within the value chain. Top responses include availability of distributors, availability of distribution networks, transportation between stakeholders, access to distribution channels for produce, availability of distributors for mid-size retailers, distribution to low-income persons, the need for transportation providers, and availability of distribution networks. 


\section{BFJ}

118,2

\section{2}

Figure 1.

Relationships among the different stages of the agri-food value chain

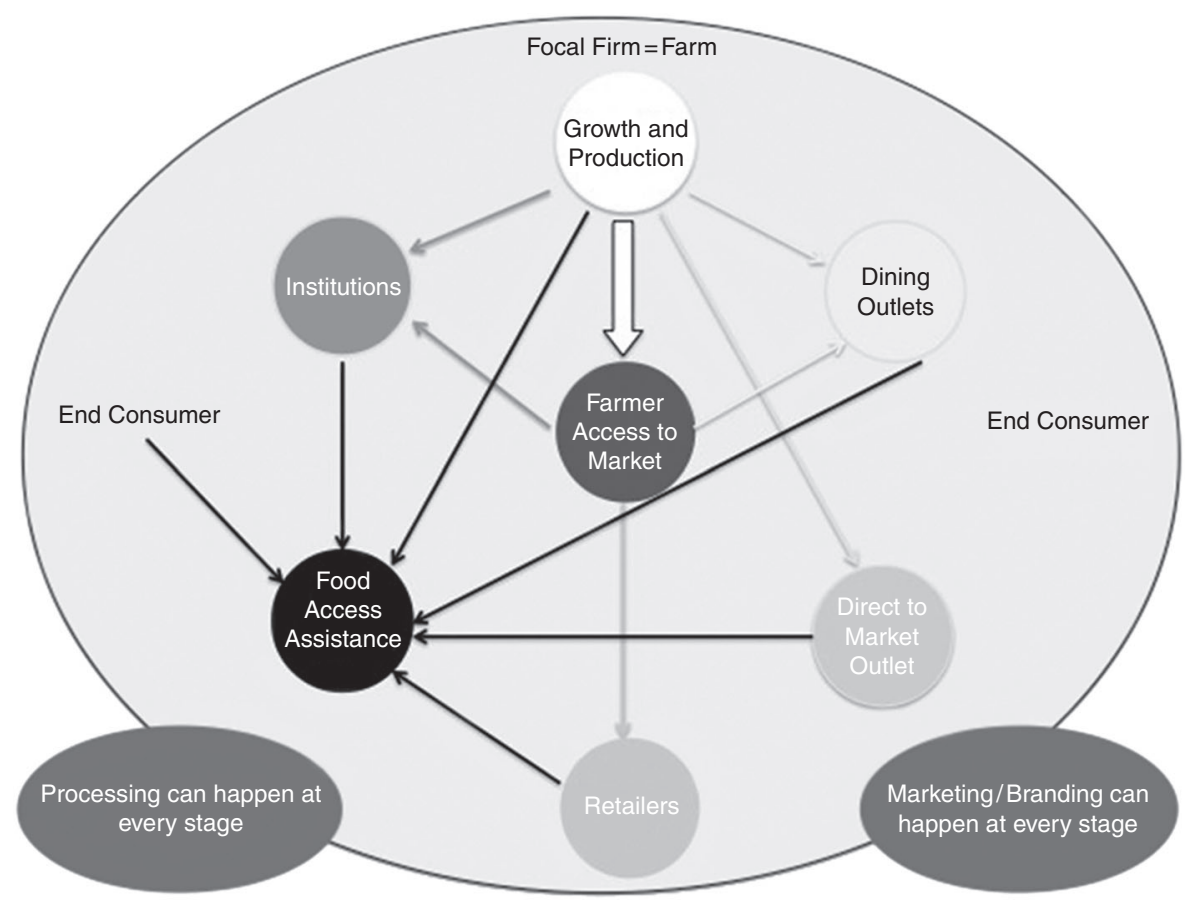

Note: An arrow to "End Consumer" is assumed from all sectors except "Farmer Access to Market"

Source: Kline et al. (2013)

\section{Affordability of food}

The issue of food affordability was a top concern of the participants, evidenced in the prevalence of produce and protein costs and availability, cost/affordability of local produce, and the availability of and access to local and organic food across all stages. In some cases, the concern was with the cost to the restaurant or to the grocery store. In others, the cost of food to the customer. Product affordability may signal a concern for equal sharing of costs and benefits across members of the supply chain. The greater the concern, the more supply chain members may feel that some costs fall predominately on them, while other supply chain member gain disproportionately.

\section{Farm profitability}

The issue of farm profitability arose primarily in relation to input costs. Critically tied to profitability is the availability of land, cost of labor, and access to capital. Also linked to farmer profitability are training programs for young farmers and succession planning.

\section{Access to markets and marketing}

The desire to reach a wider variety of viable and profitable markets was apparent in the number of critical issues identified by the participants. The top responses include increasing the access to markets providing fair compensation for farmer's products, and facilitation of cooperatives and aggregating mechanisms. Related to market access, 
promotional programs that increase market awareness and product outlets were cited as well. Responses related to the participants' desire for initiatives that would contribute to the access to markets in this area include promotion of local farmers markets, creation of "food hubs," and educational campaigns about local/organic foods.

Market access and product/market awareness suggests an ongoing concern with the current demand for product. Demand is not only affected by price, but also by the lack of consumer information about food access. Lack of information may affect demand patterns and reduce the power and influence of food producers to increase their access agri-food value chain to markets, creating a circular cause-and-effect pattern, something the producers seem to understand. Another facet of this theme, buy local movement in agriculture/food and agritourism, suggests the desire of participants to emphasize and grow $\mathrm{NC}$ as a culinary tourism destination. This theme is also related to the desire expressed by participants to expand local and regional fairs, seasonal festivals, and other foodrelated activities that promote tourism.

\section{Societal awareness and education}

Overlapping with the marketing theme, the importance of consumer education was affirmed by the participants across the stages. Concern was expressed about the need to promote consumer awareness of where food originates, teach consumers about farms and food through agritourism, improve education on why buying local foods supports local jobs, and market the benefits of local foods, in general. Social awareness and education belays a concern for more indirect economic benefits than some of the other themes. Emphasis on community awareness may make members of the NC food value chain feel they are helping to retain current customers and to promote local eating to potential customers. Education helps instill pride and interest in $\mathrm{NC}$ agricultural issues and may encourage support for public programs that fund the interests of $\mathrm{NC}$ farms and fisheries and their products.

\section{Supporting institutions}

Respondents in growth and production, farmer access to markets, and especially institutional stages cited the need for additional support from government agencies and non-profit organizations. The issue of regulatory barriers/bureaucracy made the list by institutional and direct-to-markets outlets respondents. The only mention of supporting institutions by the food access assistance respondents was an indirect reference to the infrastructure of the Supplemental Nutrition Assistance ProgramElectronic Benefit Transfer program at the state level and the desire for more direct market outlets to accept EBT, as well as the desire for support for food microsystems in low resource, rural communities. Institutions play a pivotal role in the success of value chains (Christopher, 2010).

\section{Discussion and implications}

The themes that emerged from the data represent the major issues expressed by the participants in the study, as members of the agri-food value chain in $\mathrm{NC}$. The overarching theme of connectedness suggests cooperative and collaborative attitudes of the participants with local communities, with policy makers at both the local and state level, and with other members of the value chain. Institutional connectedness concerns suggest that participants understand the importance of institutions in the value chain, not only to support and promote their own interests, but also the interests of other 
$\mathrm{BFJ}$

118,2

314

value chain members. Similarly, the items within the connectedness theme imply that the participants view their value chain relationships as holistic, even though they may interface with only one or two other value chain members.

The respondents' continuous view of the value chain is apparent in how they see themselves via their two primary roles in the chain. First, as representatives of individual links in the value chain, the participants are understandably concerned with their own profitability and access to markets. In this role, they see that overcoming gaps and barriers will allow them to succeed. Second, the finding that respondents from all stages mentioned "connectedness" as a critical issue suggests a stronger awareness of upstream and downstream stakeholders and that extending support to other members of the chain can improve the collective value chain. This finding is in direct contrast to many industries, where the value chain members are much less concerned about the chain as a whole, but rather their own improvement (Mentzer et al., 2001; Lambrecht et al., 2015).

The agricultural industry is in need of a generation of young farmers to emerge and provide a transition from today's aging farmer. Farm profitability therefore is relevant to attract a new wave of farmers to take up the trade. Inputs to farming such as seed and labor are increasingly more expensive and shifting weather patterns (e.g. drought) have rendered farmers caught in the middle of rising input prices and decreasing sales margins. While programs on succession planning and assistance for new farmers exist, these programs seem to be insufficient. Expansion of these programs would be a first step to improvement.

Access to markets and marketing and Societal awareness and education are related in that they both target the end consumer. However, awareness and education can come from multiple sources - both inside and outside the value chain. Media outlets such as online and print news, research reports, magazines, blogs, and movies can enlighten consumers to health and sustainability issues. Marketing campaigns directed at the consumer from the agricultural industry and the members of the value chain, e.g. a restaurant or grocery store can improve information about local products. Access to markets not only refers to identifying and connecting with local customers, but also increasing food related to tourism events, experiences, and outlets. Aggregating the many stakeholders involved in marketing agriculture output - advertisers, media, tourism marketers, caterers and event planners, commodity groups, government agencies, grocery stores, and restaurants - could provide a networking forum and would be a good first step in discovering synergies.

The concerns represented by the availability of food distribution theme expresses the participants' desire to find more affordable warehousing solutions, greater access to distribution networks, and efficiencies in trucking such as backhauls and rate discounts. It may signal the desire for a more integrated approach to distribution, which could be manifested in collaborative logistics relationships, information sharing, and cooperation (Mentzer et al., 2001). Addressing concerns with the related economic theme, affordability of food, may serve to reduce costs in the agri-food value chain (e.g. increased connectedness and better distribution networks).

The finding that supporting institutions emerged as a key theme was not surprising as food production, storage, transportation, and preparation processes are highly regulated by government agencies. These processes are also closely monitored by food distributors and restaurants. Institutions also aid in food distribution and connection to areas of food need. Furthermore, institutions connected to, and existing within the agri-food value chain might launch their own investigation into constituent opinions so as to pinpoint specific actions that might improve effectiveness. 
The results of this research can help members of the NC agri-food value chain in a North Carolina number of ways. First, members can apply the idea of connectedness and reach out to stakeholders that they might not have previously thought to engage. This could lead to greater transparency and collaboration and knowledge sharing in the areas of market access, technology, and government resources. Similarly, the formation of industry groups would allow members along the chain to have a greater, collective voice to help influence state and local regulating bodies. Finally, the results are especially useful to individuals or organizations that are considering becoming part of the NC agri-food value chain by providing an understanding of the current issues. For example, entrepreneurs might consider including in their marketing strategy provisions for consumer education, the role of $\mathrm{NC}$ institutions, and the variety of products available.

\section{Limitations and future research}

One limitation of this research was the subjective nature of dividing the agri-food value chain into stages, labeling issues, and assigning issues into different stages within the value chain. While efforts were made to include a complete set of response categories for each question, omissions were still made. Additionally, each stage was not represented equally, which is a limitation of using the Delphi study method for multiple groups of stakeholders. Future research should include stronger measures to solicit each category of respondent. Also, the focus of this project and subsequent lists of issues are specific to NC, and should be reevaluated when attempting to apply them in other locations. The data collected from this research suggests the need for a more extensive survey directed at the general public that will determine the public perception of the agri-food value chain in $\mathrm{NC}$, and more specifically, differences between various stakeholders and public groups.

\section{Conclusion}

Farm to table, agritoursim, and the emphasis on local food chains are all still taking hold in NC and other states and regions. Too often, researchers focus attention and efforts on the matters at hand, and rarely do stakeholders have time to reflect on the bigger picture and nuances of how members of the agri-food value chain connect. Encompassed in a value-chain analysis approach, the results provide insights that may otherwise not have been brought to light. One of the intended outcomes of this project is to inspire innovation in products, programs, processes, organization, and marketing. It is also hoped that the data collected will prompt advances that strengthen the agri-food economy, and increase availability of local, healthy food to all of the sector audiences represented in this study.

\section{References}

Bloom, J.D. and Hinrichs, C.C. (2011), "Moving local food through conventional food system infrastructure: value chain framework comparisons and insights", Renewable Agriculture and Food Systems, Vol. 26 No. 1, pp. 13-23.

Christopher, M. (2010), Logistics and Supply Chain Management: Creating Value Adding Networks, 4th ed., Financial Times Prentice Hall, Harlow.

Curtis, J., Creamer, N. and Thraves, T.E. (2010), "From farm to fork: a guide to building North Carolina's sustainable local food economy", Center for Environmental Farming Systems, available at: www.cefs.ncsu.edu/resources/stateactionguide2010.pdf 
$\mathrm{BFJ}$

118,2

316

Everett, S. and Aitchison, C. (2008), "The role of food tourism in sustaining regional identity: a case study of Cornwall, South West England", Journal of Sustainable Tourism, Vol. 16 No. 2, pp. 150-180.

Garrod, B. and Fyall, A. (2005), "Revisiting Delphi: the Delphi technique in tourism research", in Brent, W., Ritchie, P.B. and Palmer, C. (Eds), Tourism Research Methods: Integrating Theory with Practice, CABI Publishing, Cambridge, MA, pp. 85-97.

Georgiadis, P., Vlachos, D. and Iakovou, E. (2005), “A system dynamics modeling framework for the strategic supply chain management of food chains", Journal of Food Engineering, Vol. 70 No. 3, pp. 351-364.

Grandori, A. (2015), "Improving organization forms in the agri-food industry", British Food Journal, Vol. 117 No. 10, pp. 2418-2434.

Green, H., Hunter, C. and Moore, B. (1990), “Application of the Delphi technique in tourism”, Annals of Tourism Research, Vol. 17 No. 2, pp. 270-279.

Herath, J. and Hill, D. (2013), "Harnessing agricultural potentials for economic growth in North Carolina”, Sustainable Agriculture Research, Vol. 2 No. 2, pp. 142-148.

Hines, P., Rich, N., Bicheno, J., Brunt, D., Taylor, D., Butterworth, C. and Sullivan, J. (1998), "Value stream management", International Journal of Logistics Management, Vol. 9 No. 1, pp. 25-42.

Hsieh, H. and Shannon, S.S. (2005), "Three approaches to qualitative content analysis", Qualitative Health Research, Vol. 15 No. 9, pp. 1277-1288.

Inwood, S., Sharp, J., Moore, R. and Stinner, D. (2009), "Restaurants, chefs and local foods: insights drawn from application of a diffusion of innovation framework", Agricultural Human Values, Vol. 26 No. 3, pp. 177-191.

Kaipia, R., Dukovska-Popovska, I. and Loikkanen, L. (2013), "Creating sustainable fresh food supply chains through waste reduction", International Journal of Physical Distribution \& Logistics Management, Vol. 43 No. 3, pp. 262-276.

Kaplinsky, R. and Morris, M. (2013), A Handbook for Value Chain Research, International Development Research Center, Ottawa.

Kirezieva, K., Jacxsens, L., Uyttendaele, M., Van Boekel, M. and Luning, P. (2013), “Assessment of food safety management systems in the global fresh produce chain", Food Research International, Vol. 52 No. 1, pp. 230-242.

Kline, C., Joyner, L., Gurganus, C., Crawford, A., Dunning, R., Jackson, C., Kirchoff, J., McReynolds, R., O'Sullivan, J., Paynter, S., Perrett, A., Pitts, S. and Wall-Bassett, E. (2013), Identifying Gaps and Barriers Along the NC Farm-Food Value Chain: A Delphi Study, East Carolina University, Greenville, NC.

Lambrecht, E., Kuhne, B. and Gellynck, X. (2015), "Asymmetric relationships in networked agricultural innovation processes”, British Food Journal, Vol. 117 No. 7, pp. 1810-1825.

Laria, B.A., Borja, J.B. and Bentley, M.E. (2009), "Grandmothers, fathers, and depressive symptoms are associated with food insecurity among low-income first-time AfricanAmerican mothers in North Carolina", Journal of the American Dietetic Association, Vol. 109 No. 6, pp. 1042-1047.

Leat, P. and Revoredo-Giha, C. (2006), "Building collaborative agri-food supply chains: the challenge of relationship development in the Scottish red meat chain", British Food Journal, Vol. 110 Nos 4/5, pp. 395-411.

Meadows, D. and Wright, D. (2008), Thinking in Systems: A Primer, Chelsea Green Publishing, White River Junction, VT.

Mentzer, J.T., DeWitt, W., Keebler, J.S., Min, S., Nix, N.W., Smith, C.D. and Zacharia, Z.G. (2001), "Defining supply chain management", Journal of Business Logistics, Vol. 22 No. 2, pp. 1-25. 
North Carolina Department of Commerce (2013), "North Carolina tourism”, available at: www. North Carolina nccommerce.com/tourism (accessed March 19, 2015).

North Carolina Department of Commerce (2014), “The employment security commission of North Carolina”, available at: http://esesc23.esc.state.nc.us/d4/default.aspx (accessed March 19, 2015).

Ogden, J., Petersen, K., Carter, J. and Monczka, R. (2005), "Supply management strategies for the future: a Delphi study", Journal of Supply Chain Management, Vol. 41 No. 3, pp. 29-48.

Padel, S. and Midmore, P. (2005), "The development of the European market for organic products: insights from a Delphi study", British Food Journal, Vol. 107 No. 8, pp. 626-646.

Passuello, F., Boccaletti, S. and Soregaroli, C. (2015), "Governance implications of non-GM private standards on poultry meat value chains", British Food Journal, Vol. 117 No. 10, pp. 2564-2581.

Porter, M.E. (1985), Competitive Advantage: Creating and Sustaining Superior Performance, Free Press, New York, NY.

Rominger, C., Emert, S. and Ushimaru, K. (2012), "Development of a sustainable food supply chain by post harvest program - an approach to a sustainable solution to food delivery and waste problems", Global Humanitarian Technology Conference (GHTC), 2012 IEEE, pp. 230-236.

Smith, S. and Honggen, X. (2008), “Culinary tourism supply chains: a preliminary examination”, Journal of Travel Research, Vol. 46 No. 3, pp. 289-299.

Taylor, D. (2005), "Value chain analysis: an approach to supply chain improvement in agri-food chains", International Journal of Physical Distribution \& Logistics Management, Vol. 35 No. 10, pp. 744-761.

Tran, N., Bailey, C., Wilson, N. and Phillips, M. (2013), "Governance of global value chains in response to food safety and certification standards: the case of shrimp from Vietnam", World Development, Vol. 45, May, pp. 325-336.

United States Department of Agriculture: Economic Research Service (2013), "State fact sheets: North Carolina", available at: www.ers.usda.gov/data-products/state-fact-sheets.aspx\#. VA81N8JdVBk (accessed March 19, 2015).

Weatherspoon, D., Ver Ploeg, S. and Dutko, P. (2012), “An evaluation of food deserts in America”, Choices, The Magazine of Food, Farm, and Resources Issues, Vol. 27 No. 3, pp. 1-2.

$\mathrm{Yu}, \mathrm{M}$. and Nagurney, A. (2013), "Competitive food supply chain networks with application to fresh produce", European Journal of Operational Research, Vol. 224 No. 2, pp. 273-282.

\section{Corresponding author}

Jon F. Kirchoff can be contacted at: kirchoffj@ecu.edu

For instructions on how to order reprints of this article, please visit our website:

www.emeraldgrouppublishing.com/licensing/reprints.htm

Or contact us for further details: permissions@emeraldinsight.com 